\title{
Pemberitaan dan Opini Publik tentang Kedatangan Tenaga Kerja China Pada Masa Pandemi COVID-19 di Sulawesi Tenggara
}

\author{
Aldilal $^{1}$, Achmad Akbar Sanjaya ${ }^{2}$, Nur Akbar ${ }^{3}$, Muhammad Ramlan Febriansyah \\ 1,2,3,4 Magister Ilmu komunikasi, Fakultas Ilmu Sosial dan Ilmu Politik, Universitas Hasanuddin \\ Jl. Perintis Kemerdekaan, Tamalanrea Indah, Kota Makassar, Sulawesi Selatan, Indonesia \\ Email: amaldilalkomunikasi@gmail.com"; akbar.sanjo@gmail.com²; nurakbar176@gmail.com³ \\ ramlanferbriansyah.23@gmail.com ${ }^{4}$ \\ *Corresponding author
}

\begin{abstract}
The pros and cons of the arrival of Chinese workers when local people were limiting their social interactions during the COVID-19 pandemic in Southeast Sulawesi became a dominant topic in various mass media. This study aims to analyze the role of the mass media in shaping public opinion about the arrival of Chinese workers during the COVID-19 pandemic in Southeast Sulawesi. This research uses mixed methods, namely quantitative and qualitative (mixed method), researchers observe and analyze news content from three online media portals in Southeast Sulawesi from 15 June - 15 July 2020. The results of the study found: (1) several media support the existence of a policy of coming for foreign workers during the pandemic in Southeast Sulawesi, this study shows that there is a prevailing interest in the arrival of foreign workers during the pandemic; (2) Some residents do not agree with the arrival of foreign workers considering that the COVID-19 originates from China so that local residents are worried if Chinese workers add new cases of the COVID-19; (3) The results of interviews with academics also stated their attitude if they strongly disagreed with the arrival of foreign workers during the pandemic. The substance of this research contributes in the form of new policy recommendations for the government to be wiser in paying attention to the welfare of the people by employing Indonesians who dropped out of work during the COVID-19 pandemic.
\end{abstract} Keywords: Foreign Workers, Media Effects; Policies; Public Opinion; Social Media

\begin{abstract}
Abstrak
Pro dan kontra kedatangan tenaga kerja China saat masyarakat lokal sedang membatasi interaksi sosialnya pada masa pandemi COVID-19 di Sulawesi Tenggara menjadi topik yang mendominasi di berbagai media massa. Penelitian ini bertujuan untuk menganalisis peran media massa dalam membentuk opini publik tentang kedatangan tenaga kerja China pada saat pandemi COVID-19 di Sulawesi Tenggara. Penelitian ini menggunakan metode campuran yaitu kuantitatif dan kualitatif (mixed method), peneliti mengamati dan menganalisis konten berita dari tiga portal media online di Sulawesi Tenggara dari 15 Juni - 15 Juli 2020 . Hasil penelitian menemukan (1) beberapa media mendukung adanya sebuah kebijakan akan kedatangan tenaga kerja asing pada masa pandemic di sulawesi tenggara, penelitian ini menunjukan adanya sebuah kepentingan yang sedang berlaku pada kedatangan tenaga kerja asing di masa pandemic; (2) Beberapa penduduk tidak setuju kedatangan tenaga kerja asing mengingat virus corona berasal dari China sehingga warga lokal khawatirjika tenaga kerja China menambah kasus baru virus corona; (3) Hasil wawancara dengan para akademisi juga menyatakan sikap jika sangat tidak setuju akan di datangkan nya tenaga kerja asing saat masa pandemi. Substansi penelitian ini memberikan kontribusi berupa rekomendasi kebijakan baru kepada pemerintah agar lebih bijak memerhatikan kesejahteraan rakyat dengan memperkerjakan masyarakat Indonesia yang putus kerja saat masa pandemi COVID-19. Kata kunci: Pekerja Asing; Efek media; Kebijakan; Opini Publik; Media Sosial
\end{abstract}

\section{Pendahuluan}

Pandemi COVID-19 menjadi perbincangan yang mendominasi baik yang bersifat ilmiah maupun pembicaraan di berbagai media massa. Pemberitaan dan pembahasan mengenai virus yang terus menerus di media massa baik cetak, elektronik dan media online serta sosial secara tidak langsung mempengaruhi warga, membuat kepanikan dan kekhawatiran masyarakat (Triyaningsih, 2020). Keberadaan virus corona yang ditemukan di Wuhan, China menjadi perhatian publik karena penyebaran virus tersebut sangat cepat dan telah memakan banyak korban di China. Kekhawatiran publik terus meningkat ketika virus corona semakin tersebar di berbagai negara diantaranya negara yang 
terpapar adalah Indonesia. Bukti kekhawatiran publik meningkat yakni pengaruh yang signifikan mengenai kekhawatiran virus adalah dengan pemborongan barang barang sembako dan bahan makanan lain, misalnya mie dan makanan instan yang lain (Triyaningsih, 2020).

Keberadaan virus corona juga membuat perhatian khusus untuk pemerintah setiap negara, yakni bagaimana pemerintah menyikapi pandemi COVID-19 tersebut. Pemerintah Indonesia juga mengeluarkan kebijakan pembatasan sosial berskala besar yakni menghimbau masyarakat untuk menjaga jarak interaksi sosialnya.

Ketidaktahuan masyarakat akan surat edaran yang di keluarkan Kementerian Kesehatan (Kesehatan, 2020) mengenai protokol kesehatan penanganan kepulangan WNI dan kedatangan WNA dari luar negeri di pintu masuk negara dan wilayah pada situasi pembatasan sosial berskala besar (PSBB) dalam rangka pencegahan dan pengendalian COVID-19. Serta peraturan menteri hukum dan hak asasi manusia RI Nomor 11 tahun 2020 pelarangan sementara orang asing masuk wilayah Indonesia yang berlaku sejak 2 April 2020.

Kurangnya penyuluhan peraturan dan surat edaranyang berlaku secarapoin isi dankonteksnya menimbulkan ketidakpahaman masyarakat sehingga terjadi polemik publik. Seperti yang terjadi di Sulawesi Tenggara saat masa pandemi, pemerintah menjawab isu kedatangan tenaga kerja China dengan mengatakan sikap penolakan terhadap tenaga kerja China yang didatangkan dari China sebagai bentuk upaya pencegahan penularan virus COVID-19. Sikap pemerintah menolak tenaga kerja Asing (China) tersebut tidak bersinergi dengan kebijakan yang dibuat sejak awal pemerintah karena faktanya tenaga kerja China tetap didatangkan meskipun sebelumnya pemerintah menyatakan sikap penolakan tenaga kerja China di saat pandemi. Masyarakat lokal yang beranggapan telah mengikuti protokol kesehatan seperti menjaga jarak interaksinya dan menghentikan aktivitas sosialnya justru merasa berbanding terbalik dengan kebijakan pemerintah lokal di Sulawesi Tenggara yakni mendatangkan tenaga kerja China.
Sikap pemerintah Sulawesi Tenggara mengenai kedatangan 500 tenaga kerja Asing dari China di masa pandemi yang dinilai tidak konsisten menjadi dasar yang menimbulkan kritikan dan aksi penolakan tenaga kerja asing di kalangan masyarakat. Salah satu kebijakan pemerintah untuk mencegah penyebaran COVID-19 yakni dengan menjaga jarak (social and physical distancing) dan kebijakan berdiam diri di rumah (stay at home) (Tuwu, 2020).

Isu kedatangan semakin berkembang dan mengundang banyak pertanyaan ketika media nasional dan media lokal memberitakan tentang informasi kedatangan 500 tenaga kerja yang berasal dari China pada saat masa pandemi COVID-19. Isu tersebut menuai banyak perhatian masyarakat terhadap kinerja pemerintah dalam memutuskan kebijakan, ketika masyarakat lokal sedang melakukan pembatasan sosial berskala besar guna untuk memutus mata rantai penularan virus COVID-19 ini. Stereotype budaya negatif yang telah menjadi dasar pemikiran masyarakat lokal untuk berinteraksi dengan pekerja China menjadi pemicu terjadi nya konflik antara pekerja China dan masyarakat lokal (Aldilal, Unde, \& Fatimah, 2020). Cangara (2002) menyatakan bahwa penggunaan media sebagai alat untuk menyampaikan pesan paling dominan dalam komunikasi, dipengaruhi oleh pancaindra manusia seperti mata dan telinga. Terpaan berkaitan dengan seberapa banyak tayangan atau pemberitaan media, baik berupa media audio visual bahkan media online secara terus menerus (Kriyantono, 2008). Persepsi terbentuk berdasakan pengalaman tentang objek, peristiwa atau hubungan yang diperoleh dengan menyimpulkan informasi kemudian ditafsirkan. Jalaluddin (1993) menyatakan persepsi merupakan pemberian makna pada stimulus indrawi (sensory stimulus). Sensasi merupakan bagian dari persepsi, menafsirkan makna informasi indrawi tidak hanya melibatkan sensasi, terapi juga atensi.

Proses efek media pada individu harus dimulai dengan perhatian, atau 'paparan' terhadap beberapa pesan media (McQuail, 
Tabel 1. Tahap kedatangan 500 tenaga kerja China

\begin{tabular}{cccc}
\hline No & Tahap & Tanggal masuk & Jumlah pekerja China \\
\hline 1 & Pertama & $23 / 06 / 2020$ & 156 Orang \\
2 & Kedua & $30 / 06 / 2020$ & 105 Orang \\
3 & Ketiga & $10 / 07 / 2020$ & 236 Orang \\
& Total & & 500 Orang \\
\hline
\end{tabular}

Sumber: Data olahan penelitian (2020)

2010). Kedatangan 500 orang tenaga kerja China pada masa pandemi terus gencar diberitakan pada media lokal maupun media nasional. Media memengaruhi dan mendapatkan umpan balik yang cukup signifikan di kalangan masyarakat, sehingga bermunculan opini bahkan aksi unjuk rasa penolakan tenaga kerja China di Kota Kendari, Sulawesi Tenggara.

Hal tersebut tentunya tidak lepas dari peranan media memberitakan informasi kepada khalayak. Kesadaran bahwa cara media memilih, memproses, dan membentuk konten untuk tujuan mereka sendiri dapat memiliki pengaruh kuat pada bagaimana media diterima dan ditafsirkan dan dengan demikian, pada konsekuensi jangka Panjang (McQuail, 2010).

Penelitian tentang pemberitaan di media online telah dilakukan Puspitasari (2020); Boer, Pratiwi, \& Muna (2020); Aulia, Bahza, \& Goziyah (2020); Sunargo (2020). Penelitian yang membahas pemberitaan terkait pandemi yang disebabkan COVID-19 juga telah dipublikasikan Triyaningsih (2020); Rahayu (2020); Asmar (2020), Hayati \& Yoedtadi, (2020); Syaefudin \& Humardhiana (2020); dan Handariastuti, Achmad, \& Bramayudha (2020).

Manusia baik sebagai makhluk individu maupun sebagai makhluk sosial senantiasa membutuhkan informasi, kebutuhan manusia terhadap informasi sudah menjadi hal yang mutlak dalam kehidupannya, yakni selain untuk memenuhi rasa ingin tahu terhadap fenomena yang ada, manusia juga memerlukan informasi untuk bersikap dan bertindak. Informasi memang sering kali menjadi acuan dalam pengambilan keputusan untuk memecahkan masalah-masalah yang kompleks (Unde, 2014).
Media tentunya menjadi patokan informasi publik. Ada kepercayaan yang tersebar luas, mendekati kepastian, bahwa media massa adalah instrumen pengaruh yang kuat terhadap opini dan efek pada perilaku (McQuail, 2010.

Terkait bahwa media massa mempunyai kekuatan besar untuk mempengaruhi kesadaran individu yang dapat menciptakan hubungan kuat antara emosi dan konsep secara spesifik, menimbulkan ketidakberdayaan untuk melawan pengaruh media (Hutagalung, 2015).

Kehadiran tenaga kerja asing dari China di Kota Kendari tentunya menimbulkan polemik dikalangan masyarakat lokal tentang kedatangan mereka pekerja China untuk bekerja di Kota Kendari saat masyarakat Indonesia sedang membatasi interaksi sosialnya yang tentunya akan berdampak pada ekonomi masyarakat seperti banyaknya pemecatan tenaga kerja lokal dari perusahaan akibat dampak dari pandemi COVID-19. Kekhawatiran masyarakat lokal terus meningkat mengingat titik penyebaran awal virus COVID-19 tersebut berasal dari negara China sehingga masyarakat lokal khawatir akan potensi semakin meningkatnya penyebaran virus COVID-19 di Kota Kendari jika pekerja China terus berdatangan di Sulawesi Tenggara.

Di bawah kondisi ketegangan dan ketidakpastian, pemerintah, bisnis, dan elit serta kepentingan lainnya sering mencoba menggunakan media untuk memengaruhi dan mengendalikan opini (Perse, 2001).

Informasi 500 tenaga kerja China yang masuk bekerja di Indonesia khususnya di Sulawesi Tenggara akan didatangkan secara bertahap yang datanya bisa dilihat dalam Tabel 1: 
Kekhawatiran masyarakat dan emosi publik meningkat ketika kedatangan tenaga kerja China untuk bekerja di Kota Kendari tidak bisa dicegah. Masyarakat lokal sedang membatasi dan menjaga jarak interaksi sosialnya dengan masyarakat lokal lain dan di sisi lain banyak tenaga kerja lokal harus rela mendapatkan pemutusan hubungan kerja dari perusahaan dimana dia bekerja demi memutus rantai penularan Virus COVID-19. Secara realita yang dihadapi masyarakat berbanding, hal-hal tersebut menjadi salah satu indikator gejolak emosi publik yang bisa berpotensi menjadi konflik.

Hal ini berpotensi menjadi kekerasan struktural, menurut Galtung (2004) ketidakadilan yang diciptakan oleh suatu sistem yang menyebabkan manusia tidak mampu memenuhi kebutuhan dasarnya (human needs) merupakan konsep kekerasan struktural (structural violence). Kekerasan model ini dapat ditunjukkan dengan rasa tidak aman karena tekanan lembaga militer yang dilandasi oleh kebijakan politik otoriter, pengangguran akibat sistem tidak menerima sumber daya manusia dilingkunganya.

Ketakutan, kegelisahan dan kemarahan adalah reaksi yang paling kuat, yang dapat menyebabkan kepanikan atau gangguan sipil (McQuail, 2010). Dampak berita pada kebijakan dan tindakan pemerintah dengan menyoroti beberapa krisis, penyalahgunaan, bahaya, dan sebagainya dalam hal ini perhatian publik terfokus pada kedatangan tenaga kerja China saat masa pandemi terus berkembang di ranah publik sehingga mengundang banyak aksi-aksi penolakan akan kehadiran tenaga kerja China, baik di kalangan pemerintah, akademisi maupun masyarakat lokal.

Kritikan dari berbagai pihak tidak dapat meredam kedatangan 500 tenaga kerja asing yang berasal dari China. Kedatangan tetap dijadwalkan datang ke Kota Kendari Sulawesi Tenggara, meskipun aksi penolakan masih terus di lakukan oleh akademisi maupun masyarakat local. Hal ini menjadi besar potensi terjadi chaos jika ini terus terjadi besar kemungkinan akan terjadi konflik. Pengaruh media massa yang diduga, terutama dalam kaitannya dengan opini publik, sikap sosial, pilihan politik, ideologi, dan banyak pengetahuan (Graber, 1990).
Sebelum terjadi aksi penolakan tenaga kerja China, isu kedatangan tenaga kerja China sudah menjadi hal yang biasa khususnya di Sulawesi Tenggara karena keluar masuknya tenaga kerja China yang akan bekerja pada perusahaan pertambangan di Sulawesi Tenggara sudah merupakan hal yang biasa namun yang menjadi perhatian publik saat ini ketika dunia sedang dilanda pandemi COVID-19. Media massa maupun new media memberitakan tentang dampak virus corona, membuat masyarakat menjadi khawatir. Sehingga kedatangan tenaga kerja China di Sulawesi Tenggara pada masa pandemi menaruh perhatian khusus masyarakat pada isu tersebut hal itu tentunya di manfaatkan media massa lokal untuk menjadi topik berita yang menarik karena masyarakat sangat membutuhkan informasi perkembangan kedatangan tenaga kerja China di masa pandemic COVID-19.

COVID-19 menjadi fokus pemerintah, masyarakat, dan media dalam beberapa bulan ini. Fokus ini terkait kebijakan pemerintah dalam menghadapi COVID-19, sikap masyarakat menyikapi virus tersebut, dan media dalam memberitakan COVID-19.

Peran pemerintah saat keadaan darurat penularan COVID-19 telah dilakukan seperti mengeluarkan berbagai surat edaran dan peraturan, dalam hal ini juga terkait kedatangan Tenaga kerja asing di Sulawesi Tenggara pada masa pandemi membuat masyarakat bingung atau tidak memahami kondisi dan apa yang dapat diperbuat. Masyarakat terdorong untuk melakukan aksi-aksi penolakan kedatangan tenaga kerja China dan juga mengarah pada arogansi serta kekerasan terhadap akademisi maupun masyarakat lokal yang melakukan aksi demonstran penolakan terhadap tenaga kerja China tersebut. Hal ini menyebabkan tumbuhnya stereotype masyarakat jika ada kecenderungan kedatangan tenaga kerja China sangat dilindungi oleh pemerintah. Stereotype itu berkembang menjadi asumsi ketika aksi-aksi penolakan terhadap tenaga kerja China diwarnai dengan ada pembatasan atau pelarangan media massa lokal atau reporter untuk melakukan tugasnya sebagai jurnalistik guna menginformasikan publik kejadian aktual tentang aksi unjuk rasa tersebut. 


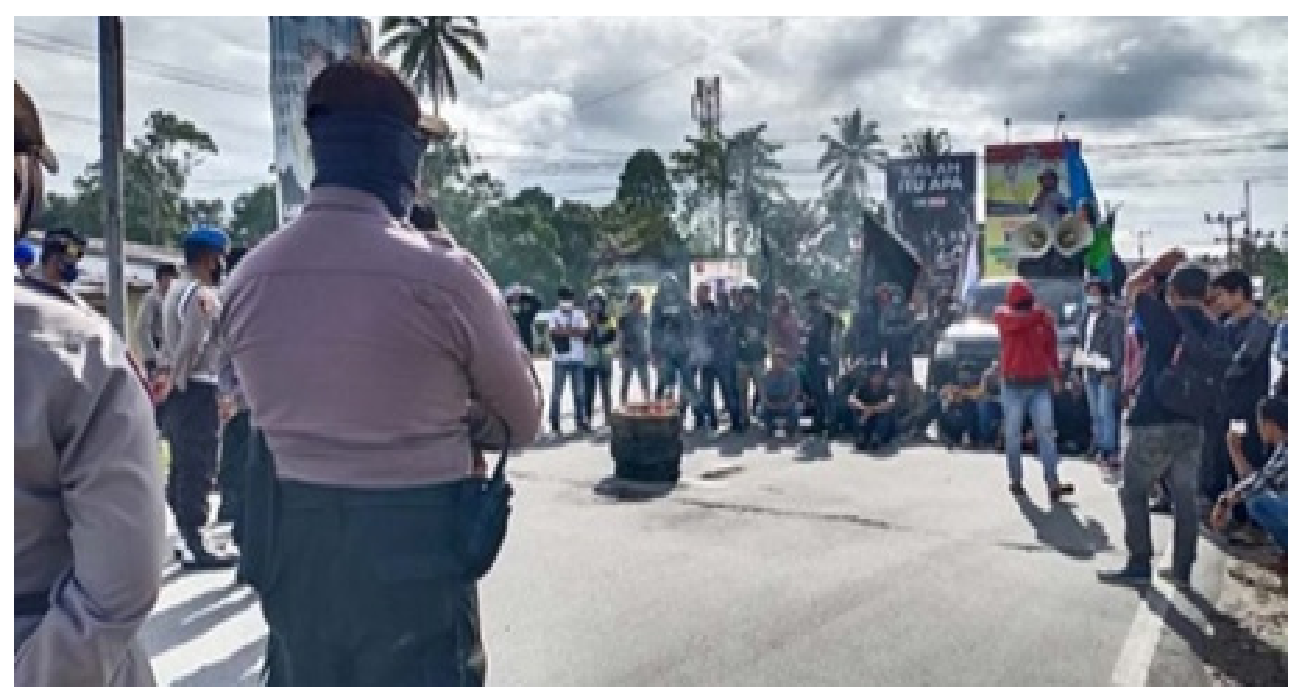

Gambar 1 Aksi Penolakan kedatangan Tenaga kerja China

Sumber: Surahmin (2020)

Media sebagai agen informasi yang secara efektif menyebarkan secara masif dalam penggunaan komunikasi virtual bebasis online (Xiong, 2012). Secara khusus mewakili opni terbentuk pada pemberitaan yang di terima.

Noelle-Neumann (1974) dalam Spiral of Silence berpendapat bahwa paradigma efek yang munculinimemilikiduadoronganutama.Pertama, media 'membangun' formasi sosial dan bahkan sejarah itu sendiri dengan membingkai gambargambar realitas (dalam fiksi maupun berita) dengan cara yang dapat diprediksi dan berpola. Kedua, orang-orang dalam audiensi membangun sendiri pandangannya tentang realitas sosial dan tempat di dalamnya, dalam interaksi dengan konstruksi simbolik yang ditawarkan oleh media.

Pendekatan ini memungkinkan baik untuk kekuatan media dan untuk kekuatan orang untuk memilih, dengan medan negosiasi yang berkelanjutan di antara keduanya, seolah-olah. Secara umum, ini adalah formulasi proses efek yang sesuai dengan perspektif mediasi. Kebijakan pemerintah dalam mendatangkan tenaga kerja China saat masa pandemi virus corona ini dan tidak mendengarkan aspirasi masyarakat yang menolak kebijakan tersebut. Hal ini membuat masyarakat menilai jika pemerintah menggunakan power kekuasaannya untuk kepentingannya tanpa mendengar masyarakatnya.
Suatu pendekatan terhadap efek media muncul yang dapat disebut sebagai 'konstruktivis sosial' (Gamson \& Modigliani, 1989). Pada dasarnya, hal ini melibatkan pandangan bahwa media memiliki efek paling signifikan dengan membangun makna. Media cenderung menawarkan pandangan 'lebih disukai' dari realitas sosial (yang ingin diterima secara luas dan dapat diandalkan).

Munculnya aksi-aksi penolakan merupakan bentuk protes keberadaan tenaga kerja asing yang di nilai dapat menambah masalah saat masa pandemi, penolakan tersebut termaksud bentuk partisipasi publik dalam menyampaikan pendapatnya. Komunikasi dan Pendapat atau Opini Publik mengemukakan bahwa pendapat publik diartikan people's response atau jawaban rakyat (persetujuan, ketidaksetujuan atau penolakan atau sikap acuh tak acuh) terhadap issues atau hal-hal yang bersifat politis dan sosial yang memerlukan perhatian umum, seperti hubungan internasional, kebijaksanaan dalam negeri, pemilihan (umum) untuk caloncalon, dan hubungan antar kelompok etnik (Berelson, 1959; Santoso Sastropoetro, 1990).

Opini publik adalah suatu hasil penyatuan dari pendapat individu-individu tentang masalah umum (Santoso Sastropoetro, 1990). Lima Faktor pemicu munculnya opini publik, 
yaitu: 1) Ada isu (presence of an issue) sebagai situasi konflik atas unsur yang mungkin tidak terdapatnya kesepakatan sehingga menimbulkan kontroversi di dalamnya; 2) Kedua Ciri publik (nature of public) keterlibatan kelompok tertentu terhadap kepentingan; 3) ketiga Pilihan yang sulit (complex of preference) yang mengkonstruksi opini sehingga muncul gerakan masyarakat mengenai isu tertentu, keempat Pernyataan opini (expression of opinion) fokus opini hanya pada isu tertentu yang di ekspresikan, kelima Jumlah orang yang terlibat (number of person involved) mempengaruhi hanya isu tertentu yang naik mengesampingkan isu lain yang dianggap tidak penting (Hennesy, 1990).

Opini publik mempunyai fungsi dalam kehidupan sosial dan individu (de Sola Pool, Frey, Scramm, Maccoby, \& Parker, 1973) menyebutkan bahwa opini publik memiliki tiga fungsi bagi seseorang, yaitu: 1) the cognitive function berarti opini publik berfungsi memberikan pengertian, sehingga dengan adanya pengertian itu seseorang dapat objektif menanggapi persoalan atau masalah yang merebak dalam masyarakat. 2) the identification function yakni opini publik berfungsi memperkenalkan pendapat - pendapat yang merupakan kesepakatan kelompok kepada individu - individu anggotanya, dan 3) the resolving of the internal function yaitu opini publik berfungsi untuk memecahkan persoalan internal suatu kelompok antara lain dengan melakukan pembagian tugas antar sesama anggota kelompok.

Penelitian tentang opini publik sudah dilakukan oleh beberapa peneliti Indrawan (2017); Juditha (2014); Syarifuddinn (2020); Alkatiri, Nadiah, \& Nasution (2020); dan Mutiara, Alkhalifi, Mayangky, \& Gata (2020).

Berdasarkan latar belakang yang diuraikan di atas maka penelitian ini bertujuan untuk menganalisis isi liputan berita dalam portal media massaonlinelokalkhususnyapemberitaantentang kedatangan tenaga kerja China di masa pandemi COVID-19 di Sulawesi Tenggara, Indonesia.

\section{Metode Penelitian}

Penelitian ini menggunakan metode campuran (mixed methods) yaitu kuantitatif dan kualitatif. Metode mixed methods dipilih karena peneliti menganggap metode ini mampu memberikan pemahaman yang mendalam dan analisis yang berbasis data yang memperkuat hasil penelitian. Mixed methods research is an approach to inquiry that combines or associates both qualitative and quantitative forms. It involves philosophical assumptions, the use of qualitative and quantitative approaches, and the mixing of both approaches in a study. Thus, it is more than simply collecting and analyzing both kinds of data; it also involves the use of both approaches in tandem so that the overall strength of a study is greater than either qualitative or quantitative research (Creswell \& Plano, 2017).

Pendekatan kuantitatif dengan metode deskriptif, karena data berupa angkaangka yang bersifat kuantitatif kemudian dianalisis menggunakan kualitatif dengan menginterpretasikan berdasarkan hasil pengkodingan dan wawancara secara langsung agar memperkuat hasil analisis yang diperoleh. Analisis isi (content analysis) merupakan suatu metode untuk mempelajari dan menganalisis komunikasi secara sistematik, objektif, dan kuantitatif terhadap pesan yang tampak (Wimmer \& Dominick, 2011). Pembentukan opini juga di kenal sebagai analisis terhadap isi konten, yang bertujuan mengidentifikasi opini yang terbentuk (Petz, 2015) serta dalam penelitian ini telah terbukti bahwa opini memiliki dampak yang jelas akan sebuah peristiwa.

Penulis menggunakan formula Holsti atau rumus Holsti dalamuji ini untuk dapat menghitung derajat reliabilitas dari alat ukur diatas, yaitu:

$$
C R=\frac{2 M X}{N 1+N 2} \times 100 \%
$$

Keterangan:

CR: Coefficient reliability (reliabilitas antarcoder)

M: Jumlah coding yang sama (disetujui oleh semua coder)

N1: Jumlah coding yang dibuat oleh coder 1 N2: Jumlah coding yang dibuat oleh coder 2 
Tabel 2 Uji Reliabilitas

\begin{tabular}{|c|c|c|c|c|c|c|c|c|c|}
\hline & \multicolumn{2}{|r|}{$\mathrm{N}=\mathbf{2 8}$} & \multicolumn{2}{|r|}{$N=8$} & \multicolumn{2}{|r|}{$\mathrm{N}=17$} & \multirow[t]{2}{*}{ Pro } & \multirow[t]{2}{*}{ Kontra } & \multirow[t]{2}{*}{ Jumlah } \\
\hline & Setuju & Tidak setuju & Setuju & Tidak setuju & Setuju & Tidak setuju & & & \\
\hline & 10 & 18 & 8 & 0 & 4 & 13 & 22 & 32 & 54 \\
\hline$\%$ & $36 \%$ & $64 \%$ & $100 \%$ & - & $24 \%$ & $76 \%$ & $41 \%$ & $59 \%$ & \\
\hline
\end{tabular}

Sumber: Hasil olahan data (2020)

Tujuan penelitian melihat dan menganalisa sebuah fenomena dari isi pemberitaan portal media online Sulawesi tenggara pada penasultra.id, zonasultra.com dan inilahsultra. com pada periode 15 Juni - 15 Juli 2020 mengenai kedatangan warga tenaga kerja asing dalam masa pandemi COVID-19 di Sulawesi tenggara yang diberitakan kepada khalayak.

Pemilihan portal media online di ambil menggunakan metode purposive sampling pemilihan acak berdasarkan data dewan pers yang secara administrasi diakui sebagai portal media online legal berdiri dan kredibel secara etika jurnalistik dalam penyajikan pemberitaan. Adapun sampel pembaca juga diambil berdasarkan metode purposive sampling yang berdomisili di Sulawesi tenggara yaitu mahasiswa yang terlibat aksi demonstrasi penolakan kedatangan tenaga kerja asing China masyarakat lokal dan wartawan lokal.

Pengujian reabilitas dalam penelitian ini menggunakan jenis reabilitas antar-coder, dimana pemberian pengkodingan sebagai landasan dalam menganalisis pemberitaan pada portal media online pro atau kontra terhadap kedatangan tenaga kerja asing cina. Dari 54 isu dari-pemberitaan tersebut Pro = Ya didapatkan 22 atau 44 hasil koding yang sama dengan tingkat kepercayaan $81 \%$ dan dianggap memadai dalam kebutuhan penelitian ini. Perhitungan angka minimum hasil toleransi ialah 0,7 atau $70 \%$ dalam formula Holsti sebagai alat ukur penentu reliable. Begitupun sebaliknya apa bila hasil dibawah 0,7 berarti coding sheet ini bukan alat yang reliable (Eriyanto, 2011).

$$
C R=\frac{22.2 X}{54} \times 100 \%=81 \%
$$

\section{Hasil Penelitian dan Pembahasan}

Hasil penelitian menunjukkan bahwa uji realibilitas terlihat pada Tabel 2 .

Analisis isi pemberitaan media online lokal yang terdiri dari zonasultra.com, penasultra. id, dan inilahsultra.com periode berita 15 Juni-15 Juli 2020

Pemberitaan yang dilakukan oleh tiga media online lokal di Sulawesi Tenggara yakni zonasultra.com, Penasultra.id, Inilahsultra.com mengenai isu kedatangan tenaga kerja asing yang berasal dari China pada periode 15 Juni hinga 15 Juli, terdapat 54 topik mengenai isu kedatangan tenaga kerja asing di masa pandemi di provinsi Sulawesi Tenggara. Berita yang dimunculkan dari ketiga media lokal tersebut lebih membahas mengenai penolakan masyarakat lokal kedatangan tenaga kerja asing ini. Beberapa topik menyajikan kebijakan pemerintah dalam bersikap mengenai penolakan masyarakat. Kebijakan dan pembahasan DPRD Provinsi Sulawesi Tenggara juga menjadi bahan berita dari ketiga media online tersebut. Jumlah berita yang disajikan ketiga media online tersebut bervariatif.

Media online zonasultra.com (Tabel 3) mengangkat isu kedatangan tenaga kerja china sebanyak 28 kali. Berita yang disajikan pun lebih terhadap penolakan yang dilakukan dari berbagai kalangan. Peneliti menyatakan bahwa media ini cukup update mengangkat isu tenaga kerja China. Media zonasultra.com mengangkat berita mulai dari kedatangan hingga pengawalan yang dilakukan oleh pihak pemerintah hingga penolakan yang dilakukan oleh beberapa kalangan. Isu yang diberitakan oleh media ini 
Tabel 3 Media Online zonasultra.com Coding Sample

\begin{tabular}{cccc}
\hline News & Coder & Agree (A) & Dissagree (D) \\
\hline 1 & 1 & A & \\
2 & 1 & A & D \\
3 & 0 & A & D \\
4 & 1 & & D \\
5 & 0 & & D \\
6 & 0 & & D \\
7 & 0 & & D \\
8 & 0 & & D \\
9 & 0 & A & D \\
10 & 0 & & D \\
11 & 0 & A & \\
12 & 1 & & D \\
13 & 0 & A & D \\
14 & 0 & & \\
15 & 1 & A & D \\
16 & 0 & & \\
17 & 1 & A & D \\
18 & 0 & & \\
19 & 1 & A & D \\
20 & 0 & & D \\
21 & 0 & & \\
22 & 1 & 0 & A \\
23 & 0 & $\ldots$ &
\end{tabular}

Sumber: Hasil olahan data (2020)

menghadirkan beberapa narasumber, mulai dari para aparat yang mendukung hingga masyarakat yang menolak kedatangan tenaga kerja asing. Media ini memberitakan 28 kali isu tenaga kerja asing dengan komposisi sebagai berikut: 1) Berita kebijakan pemerintah yang mendukung tenaga kerja asing sebanyak 10 topik atau sebanyak 36\%, topik yang di angkat lebih terhadap kebijakan kedatangan tenaga kerja asing; dan 2) berita akan penolakan sebanyak 18 topik atau sebanyak $64 \%$ yang dipublikasikan di portal beritanya. Media ini menyorot beberapa kalangan yang menolak kedatangan tenaga kerja asing, melalui aksi demo mahasiswa hingga anggota DPRD yang melakukan penolakan.

Pada penasultra.id menerbitkan sebanyak 8 topik berita (Tabel 4). Peneliti menghitung jumlah pada periode yang sama yang dilakukan pada media online zonasultra.com. Topik yang disajikan pun lebih terhadap dukungan yang diberikan pada kebijakan yang dilakukan untuk tenaga kerja asing dengan komposisi sebagai berikut: 1) Berita kebijakan yang mendukung akan kedatangan tenaga kerja asing sebanyak 8 atau $100 \%$ berita dengan topik dukungan yang dilakukan oleh pemerintahan; dan 2) pada periode yang sama peneliti tidak menemukan adanya berita penolakan yang dilakukan oleh masyarakat.
Tabel 4 Media Online penasultra.id Coding Sample

\begin{tabular}{cccc}
\hline News & Coder & Agree (A) & Dissagree (D) \\
\hline 1 & 1 & $\mathrm{~A}$ & \\
2 & 1 & $\mathrm{~A}$ & \\
3 & 1 & $\mathrm{~A}$ & \\
4 & 1 & $\mathrm{~A}$ & \\
5 & 1 & $\mathrm{~A}$ & \\
6 & 1 & $\mathrm{~A}$ & \\
7 & 1 & $\mathrm{~A}$ & \\
8 & 1 & $\mathrm{~A}$ & \\
& Total & 8 & \\
& $\%$ & $100 \%$ & \\
\hline
\end{tabular}

Sumber: Hasil olahan data (2020)

Pada media online inilahsultra.com menerbitkan berita dengan topik kedatangan tenaga kerja asing pada masa pandemi pada periode ini 15 Juni hingga 15 Juli sebanyak 17 topik berita dengan kedatangan tenaga kerja asing (Tabel 5). Pada periode ini topik yang disajikan oleh media inilahsultra.com lebih terhadap tindakan penolakan yang dilakukan oleh berbagai kalangan di masyarakat Sulawesi Tenggara. Kebijakan penolakan pun dari berbagai kalangan. Peneliti melihat penolakan terhadap tenaga kerja asing tidak hanya datang pada kalangan mahasiswa namun juga berdatangan dari beberapa anggota dewan yang terdapat pada media online inilahsultra,com sebanyak 8 topik berita penolakan yang di lakukan oleh mahasiswa dan 5 topik penolakan yang dilakukan oleh anggota dewan. Berikut rincian topik tenaga kerja Asing yang di beritakan oleh inilahsultra.com: 1) Terdapat 4 atau sebanyak 24 $\%$ topik berita yang mendukung kebijakan yang dilakukan oleh pemerintah dalam mendatangkan tenaga kerja asing; dan 2) terdapat 13 berita atau sebanyak $76 \%$ topik pemberitaan yang menolak kedatangan tenaga kerja asing yang di datangkan pada periode pandemi.

Berdasarkan hasil temuan penelitian, beberapa media mendukung adanya sebuah kebijakan kedatangan tenaga kerja asing 
Tabel 5 Media Online inilahsultra.com Coding Sample

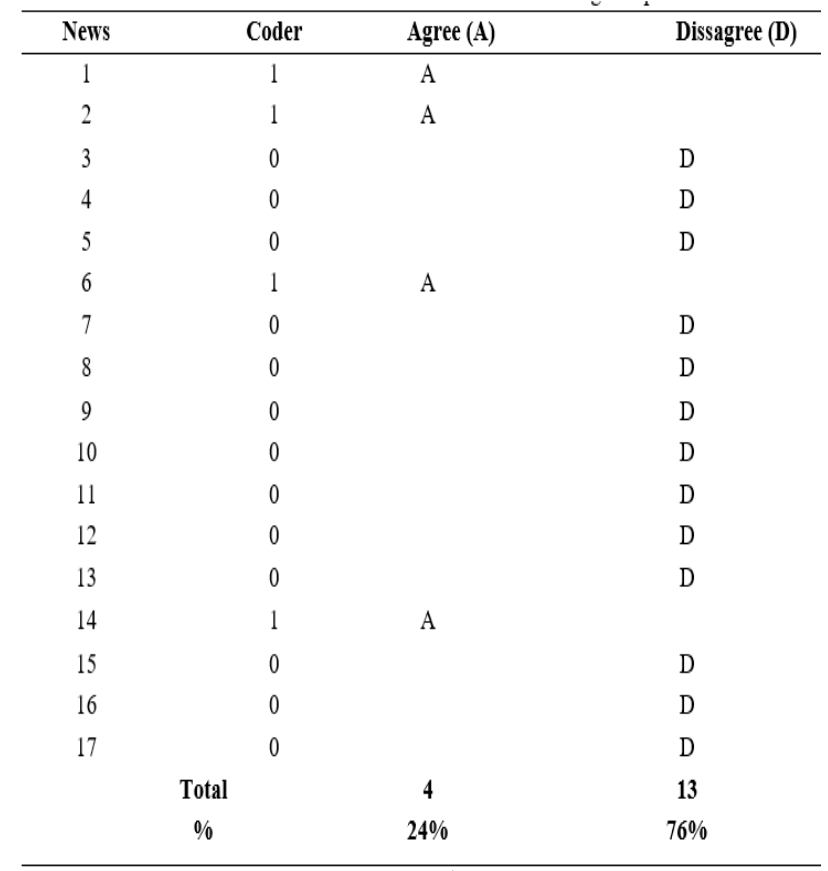

Sumber: Hasil olahan data (2020)

pada masa pandemi di Sulawesi Tenggara. Penelitian ini menunjukan adanya sebuah kepentingan yang sedang dijalan pada kedatangan tenaga kerja asing di masa pandemi. Kekhawatiran ditengah masyarakat simpang siurnya informasi mengenai tenaga kerja asing bisa membuat ketidakpercayaan masyarakat mengenai kebijakan yang di keluarkan oleh pemerintah. Beberapa lapisan masyarakat membuat aksi penolakan mengenai kebijakan ini. Munculnya aksi-aksi penolakan merupakan bentuk protes keberadaan tenaga kerja asing yang dinilai bisa menambah masalah saat masa pandemi. Penolakan tersebut termaksud bentuk aspirasi publik dalam menyampaikan pendapatnya.

Kebijakan pemerintah dalam mendatangkan tenaga kerja China saat masa pandemi COVID-19 dan tidak mendengarkan aspirasi masyarakat yang menolak kebijakan tersebut. Hal ini membuat masyarakat menilai jika pemerintah menggunakan power kekuasaannya untuk kepentingannya tanpa mendengar masyarakatnya. Menurut Dahrendorf jika konflik kepentingan menjadi fakta tak terhindarkan dari mereka yang memiliki kekuasaan dan tidak memiliki kekuasaan. Kekuasaan adalah lasting source of friction (Wallace \& Wolf, 1995).

Peneliti mendapatkan adanya gejolak yang sedang berlangsung mengenai pemberitaan di media sosial. Peneliti mencoba membandingkan tiga media online lokal mengenai pemberitaan yang membahas topik pemberitaan tenaga kerja asing yang datang pada masa pandemi. Peneliti melihat adanya aspek pembentukan opini publik yang tidak berimbang yang dilakukan oleh ketiga media online lokal tersebut. Temuan lainnya terdapat 54 topik berita dari ketiga media online ini yang membahas tenaga kerja asing dengan persentase sebagai berikut: persentase penolakan sebesar $59 \%$, persentase penerimaan tenaga kerja asing sebesar 41\%. Besaran angka persentase ini mengacu pada persentase penerbitan berita dengan topik tenaga kerja asing.

Media online zonasultra.com mengangkat topik sebanyak 28 pemberitaan. Persentase penolakan sebesar $64 \%$. Topik ini muncul sebanyak 18 berita. Sepuluh pemberitaan yang mendukung kebijakan pemerintah mendatangkan tenaga kerja asing sebanyak 36\%. Media online penasultra.id mendukung $100 \%$ kebijakan yang dibuat oleh pemerintah mendatangkan tenaga kerja asing. Temuan ini terlihat adanya topik berita yang diangkat oleh penasultra. com sebanyak delapan berita dengan topik kedatangan tenaga kerja asing. Pemberitaan itu mendukung mengenai kedatangan tenaga kerja sing sebagai wujud pembangunan daerah dan sebagai bentuk kerja sama pemerintah dalam membangun Sulawesi Utara. Media inilahsultra. com memberitakan topik tenaga kerja asing sebanyak 17 berita dengan perenstase $76 \%$. Pemberitaan penolakan dengan berita sejumlah 13 buah, sedangkan yang mendukung kebijakan ini $24 \%$ dengan berita sebanyak 4 berita. Opini publik merupakan pengidentifikasian pola pengguna media yang mempunyai pengaruh secara langsung. Perkembangan internet membuat percepatan opini publik secara online terbentuk berkaitan dengan masyarakat yang secara aktif mencari bahkan dapat mengelolah opini di keadaan apapun dari 
berbagai sumber bahkan yang tidak kredibel sekali pun, yang dapat menimbulkan efek yang cukup buruk (Weeks, 2015). Menurut McQuail (2010) peranan media sebenarnya lebih berpengaruh dalam cara-cara tertentu pada saat krisis atau kesadaran yang meningkat.

Pada saat-saat perubahan dan ketidakpastian, juga sangat mungkin bahwa orang lebih tergantung pada media massa sebagai sumber informasi dan panduan (Lowery, 1995).

Peneliti menghimpun beberapa respon dari masyarakat mengenai topik tenaga kerja asing yang diberitakan pada tiga media online lokal tersebut. Peneliti menghimpun respon dari beberapa kalangan seperti mahasiswa, masyarakat lokal, dan wartawan lokal. Selain melakukan analisis isi pemberitaan, peneliti juga melakukan wawancara kepada informan yang terdiri dari mahasiswa yang melakukan demonstrasi, masyarakat lokal, dan wartawan yang bekerja di media lokal di Sulawesi Tenggara.

Pendapat informan tentang kedatangan tenaga kerja China saat masa pandemi COVID-19 rata-rata memiliki kesamaan dalam mengeluarkan pendapat, yaitu sangat tidak setuju dengan kedatangan tenaga kerja China di Indonesia di masa pandemi. Ada beberapa indikator yang membuat mereka tidak setuju, diantaranya mengingat COVID-19 berasal dari China sehingga warga lokal khawatir jika tenaga kerja China menambah kasus baru COVID-19 di daerah tempat mereka tinggal. Masyarakat lokal menyatakan bahwa kebijakan pemerintah mendatangkan tenaga kerja China saat pandemi sangat tidak tepat sasaran mengingat banyaknya pekerja lokal mengalami pemutusan hubungan kerja.

Hasil wawancara dengan para akademisi menyatakan sikap jika sangat tidak setuju dengan didatangkan saat masa pandemi dan para akademisi juga menyatakan sikap melakukan unjuk rasa menuntut pemerintah untuk mengambil kebijakan secara berdaulat mengingat Indonesia sedang krisis karena pandemi virus corona. Hasil wawancara dengan para jurnalis lokal menyatakan bahwa tidak setuju karena masih banyak pengangguran dan kebijakan melakukan impor tenaga kerja dari China sangat tidak adil mengingat banyaknya pengangguran dampak dari COVID-19.

Temuan hasil wawancara peneliti tentang peran media saat masa pandemi ini adalah ratarata informan masyarakat lokal menyatakan jika peran media massa dalam menyikapi isu tenaga kerja China yaitu media massa sudah sangat membantu menginformasikan perkembangan isu tenaga kerja China dan terus memperbaharui informasinya, baik di media massa maupun media sosial. Menurut pendapat informan mahasiswa tentang media massa dalam menyikapi isu tenaga kerja China jika ada keraguan dan ketidakpercayaan terhadap media. Informan menambahkan bahwa sebagian jurnalis hanya memberitakan kedatangan tenaga kerja China tanpa menyoroti kebijakan pemerintah itu sendiri. Rata-rata akademisi menilai bahwa memiliki keraguan terhadap informasi yang disajikan media tentang kedatangan tenaga kerja China di masa pandemi, dan pendapat informan dari kalangan jurnalis lokal yaitu memberitakan ke publik dengan independen dan media memberi informasi sesuai fakta yang ada, mengkritik jika ada yang perlu diperbaiki.

Penolakan kedatangan tenaga kerja China semakin berkembang dan juga mengarah pada arogansi dan kekerasan terhadap akademisi maupun masyarakat lokal yang melakukan aksi demonstrasi sehingga tumbuh stereotype masyarakat jika ada kecenderungan kedatangan tenaga kerja China sangat dilindungi oleh pemerintah. Stereotype itu berkembang menjadi asumsi (Noelle-Neumann, 1974), ketika aksiaksi penolakan diwarnai pembatasan atau pelarangan media massa lokal atau reporter untuk melakukan tugasnya sebagai jurnalistik guna menginformasikan publik akan kejadian aktual tentang aksi unjuk rasa tersebut.

\section{Simpulan}

Penelitian ini menyimpulkan: 1) beberapa media mendukung adanya kebijakan kedatangan tenaga kerja asing pada masa pandemik di Sulawesi Tenggar. Penelitian ini menunjukan adanya kepentingan yang sedang dijalankan 
pada kedatangan tenaga kerja asing di masa pandemi; 2) Beberapa penduduk tidak setuju kedatangan tenaga kerja asing mengingat virus corona berasal dari China sehingga warga lokal khawatir tenaga kerja China menambah kasus baru virus corona; dan 3) Para akademisi menyatakan sikap sangat tidak setuju terhadapat kedatangan tenaga kerja asing saat masa pandemi COVID-19. Penelitian ini memberikan kontribusi penelitian berupa rekomendasi kebijakan baru kepada pemerintah agar lebih bijak dalam mendatangkan tenaga kerja asing di saat pandemi COVID-19 dikarenakan masih banyak masyarakat setempat yang mengalami pemutusan hubungan kerja dan kekhawatiran masyarakat terhadap penyebaran COVID-19. Pemerintah seharusnya lebih mengedepankan masyarakat Indonesia yang putus kerja demi kesejahteraan masyarakat setempat.

\section{Daftar Pustaka}

Aldilal, Unde, A. A., \& Fatimah, J. M. (2020). Prasangka Konflik \& Kecemburuan Sosial Antara Pekerja China dan Masyarakat Lokal di PT. Virtue Dragon Nikel Industri Sulawesi Tenggara. Jurnal Ilmu Komunikasi (J-IKA), 7(2), 155-165. Alkatiri, A. B. M., Nadiah, Z., \& Nasution, A. N. S. (2020). Opini Publik Terhadap Penerapan New Normal Di Media Sosial Twitter. CoverAge: Journal of Strategic Communication, 11(1), 1926. Diakses dari http://103.75.102.195/ index.php/coverage/article/view/1728 Asmar, A. (2020). Media dan Realitas Sosial: Refleksi dan Representasi Pemberitaan Virus Corona. Al-Din: Jurnal Dakwah dan Sosial Keagamaan. 6(1). doi:10.35673/ajdsk.v6i1.851 Aulia, N., Bahza, Z. A., \& Goziyah, G. (2020). Jenis Paragraf dalam Surat Kabar Online CNN Bertema Virus Corona. Jurnal Sasindo, 8(1), 1-11. http:// dx.doi.org/10.32493/sasindo.v8i1.1-11
Berelson, B. (1959). The State of Communication Research. Public Opinion Quarterly. https://doi.org/10.1086/266840 Boer, K. M., Pratiwi, M. R., \& Muna, N. (2020). Analisis Framing Pemberitaan Generasi Milenial dan Pemerintah Terkait Covid-19 di Media Online. Communicatus. 4(1), 85104. https://doi.org/10.15575/cjik.v4i1.8277 Cangara, H. (2002). Pengantar Ilmu Komunikasi (Cetakan Keempat). Jakarta: PT Rajagrafindo Persada. Creswell, J., \& Plano, V. (2017). Designing and Conducting Mixed Methods Research - John W. Creswell, Vicki L. Plano Clark. SAGE Publications. de Sola Pool, I., Frey, F. W., Scramm, W., Maccoby, N., \& Parker, E. B. (1973). Handbook of Commmunication. Rand McNally Sociolgy Series. Eriyanto. (2011). Analisis Isi: Pengantar Metodologi untuk Penelitian Ilmu Komunikasi dan Ilmu-ilmu Sosial Lainnya. Jakarta: Kencana. Galtung, J. (2004). Violence, War, and Their Impact. On Visible and Invisible Effects of Violence. Forum for Intercultural Philosophy 5. Gamson, W. A., \& Modigliani, A. (1989). Media Discourse and Public Opinion on Nuclear Power: A Constructionist Approach. American Journal of Sociology. https://doi.org/10.1086/229213 Graber, D. (1990). Seeing is remembering: how visuals contribute to TV news. Journal of Communication, 134-55. Handariastuti, R., Achmad, Z. A., \& Bramayudha, A. (2020). Analisis Framing Berita Pemberhentian PSBB Surabaya Raya di Media Online Kompas.com dan Suarasurabaya.net. Jurnal Ilmu Komunikasi, 10(2). 156-176. https:// doi.org/10.15642/jik.2020.10.2.156-176

Hayati, H. N., \& Yoedtadi, M. G. (2020). Konstruksi Berita Covid-19 di Kompas. com dan Tribunnews.com. Koneksi, 4(2). 243-250. doi:10.24912/kn.v4i2.8114 
Hennesy, B. (1990). Pendapat Umum (Edisi 4). Jakarta: Penerbit Erlangga. Hutagalung. (2015). Teori-teori Komunikasi dalam Pengaruh Psikologi. Jakarta: Indeks.

Indrawan, R. M. J. (2017). Dampak Komunikasi Politik dan Opini Publik terhadap Perilaku Masyarakat. Jurnal Moestopo. 16(2). https://doi.org/10.32509/wacana.v16i2.14

Jalaluddin, Rakhmat, (1993). Psikologi Komunikasi. Bandung: Remaja Rosdakarya.

Juditha, C. (2014). Opini Publik terhadap Kasus "KPK Lawan Polisi" dalam Media Sosial Twitter. Jurnal Pekommas. 17(2), 61-70.

Kesehatan, K. (2020). Surat Edaran Menteri Kesehatan Nomor H K. $02.01 /$ M E N K S / $313 / 2020$. Kriyantono, R. (2008). Public Relations Writing: Teknik Produksi Media Public Relations dan Publisitas Korporat. Jakarta: Kencana.

Lowery, S. . (1995). Milestones in Mass Communication Study. New york: Longman.

McQuail, D. (2010). News, public opinion and political communication. In McQuail's mass communication theory.

Mutiara, T. A., Alkhalifi, Y., Mayangky, N. A., \& Gata, W. (2020). Analisis Sentimen Opini Publik Mengenai Larangan Mudik pada Twitter Menggunakan Naïve Bayes. Jurnal CoreIT: Jurnal Hasil Penelitian Ilmu Komputer dan Teknologi Informasi, 6(2). http://dx.doi.org/10.24014/coreit.v6i2.9727

Noelle-Neumann, E. (1974). The Spiral of Silence: a theory. Journal of Communication .

Perse, E. M. (2001). Media Effects and Society. In Media Effects and Society. https://doi.org/10.4324/9781410600820

Petz, G. K. (2015). Computational approaches for mining user's opinions on the web 2.0. Information Processing and Management, 51(4), 510-519.

Puspitasari, K. (2020) Kapabilitas dan Kepemimpinan Anies Baswedan dalam Penanganan Banjir Jakarta di Detik. com dan Kompas.com. Jurnal Ilmu Komunikasi, 18(2), 221-238. https:// doi.org/10.31315/jik.v18i2.3505

Rahayu, R. N. (2020). Analisis Berita Hoax Covid-19 di Media Sosial di Indonesia. Intelektiva, 1(9), 60-73. Diakses dari https://jurnalintelektiva. com/index.php/jurnal/article/view/122 Rakhmadani, R. (2020) Objektivitas Media di Tengah Pandemi Covid-19: Analisis Isi Berita tentang Penerapan New Normal di Indonesia pada Media Tirto.id. Jurnal Audiens. 1(2), 243-252. https://doi.org/10.18196/ja.12030

Santoso Sastropoetro. (1990). Pendapat Publik, Pendapat Umum, dan Pendapat Khalayak dalam Komunikasi Sosial. Bandung: Remaja Rosdakarya. Sunargo, S. (2020). Analisis Wacana Kritis Berita 'Tentang Social Distance, Cara Pemerintah Cegah Penyebaran Virus Corona' di Detik. com. Communicology, 8(1), 131-152. https:// doi.org/10.21009/Communicology.013.010

Surahmin, I. (2020). Akses Bandara Haluoleo Kembali Diblokade Massa Penolak TKA China. Zonasultra.Com. Syaefudin, M., \& Humardhiana, A. (2020). Pemberitaan Virus Corona di TV One dan Kompas TV. Orasi, 11(1), 87-104. doi:10.24235/orasi.v11i1.6291.g3214 Syarifuddinn, M. (2020). Analisis Sentimen Opini Publik Mengenai COVID-19 pada Twotter Menggunakan Metode Naïve Bayes dan KNN. Inti Nusantara Mandiri. 15(1), 2328. https://doi.org/10.33480/inti.v15i1.1347

Triyaningsih, H. (2020). Efek Pemberitaan Media Massa Terhadap Persepsi Masyarakat Tentang Virus Corona (Studi Kasus; Masyarakat di Pamekasan). Meyarsa, 1(1).

Tuwu, D. (2020). Kebijakan Pemerintah dalam Penanganan Pandemi COVID-19. Journal Publicuho, 3(2), 267-278.

Unde, A. A. (2014). Televisi \& Masyarakat Pluralistik. Prenadamedia group.

Wallace \& Wolf.(1995). Reading in contemporary sociological theory from modernity to post modernity. New Jersey: Prentice Hall.

Weeks, B. A.-A. (2015). Online influence? Social media use,opinion leadership, and political persuasion. International Journal of Public Opinion Study, 29(2), 214-239.

Wimmer, R. D., \& Dominick, J. R. (2011). Mass media research: an introduction. In Wadsworth Series.

Xiong, F. L. (2012). Model penyebaran informasi berdasarkan mekanisme retweeting untuk media sosial online. Physics Letters A, 376(30. 2103-2108). 